\title{
A SYSTEMATIC REVIEW ON TRAVEL MEDICINE PRACTICE TO CONTROL TRANSMISSION OF COMMUNICABLE DISEASES
}

\author{
Herpani Sudirman, Adang Bachtiar \\ Department of Health Policy and Administration, Faculty of Public Health, \\ Universitas Indonesia
}

\begin{abstract}
Background: The number of international travelers is estimated at 900 million per year and is projected to reach 1.6 billion per year in 2020. Travel medicine is devoted to the health of travelers who visit foreign countries. It is an interdisciplinary specialty concerned not only with prevention of communicable diseases during travel but also with the personal safety of travelers and the avoidance of environmental risks. This study aimed to review systematically the travel medicine practice to control transmision of communicable diseases.
\end{abstract}

Subjects and Method: A systematic review was conducted by collecting several studies that examined travels medicine practice related to the spread of communicable disease. A total of 11 articles was selected for this study. The data were analyzed using narrative synthesis and a review of travel medicine practice.

Results: Travel medicine practice was related to effective anticipation of communicable diseases including pre-travel health advice service, guideline, vaccination, and post-trip care. These practices could not be underestimated because virus and disease could easily spread when the tourists were not fit and exhausted during the trip. It was necessary for tourists to anticipate the spread of disease by knowing certain disease in the country and to have them vaccinated before traveling.

Conclusion: Travel medicine practice has a significant impact on disease transmission anticipation among travellers/ tourists.

Keywords: travel medicine practice, communicable disease spread, tourists

\section{Correspondence:}

Herpani Sudirman. Department of Health Policy and Administration, Faculty of Public Health, Universitas Indonesia, F Building $1^{\text {st }}$ Floor Kampus Baru UI Depok 16424, Indonesia. Email: herpani.sudirman@ui.ac.id. Mobile: 0811588911.

\section{BACKGROUND}

Travel medicine is a medical discipline that deals with prevention of infectious diseases during international travel as well as the personal safety of travelers and the avoidance of environmental risks during travel (Hill et al., 2006).

The travel medicine practices must be avoided the risk of infectious diseases during travel time. There are some infectious diseases that should be anticipated in some certain countries, such as measles, cholera, dengue fever, yellow fever, meningitis, hepatitis A, hepatitis B, hepatitis C, and even HIV/AIDS, etc. To overcome these infectious diseases in certain countries, it is needed to vaccinate travelers corresponding to the travel destination country, for instance Japanese Encephalitis vaccination (JE) is a mandatory vaccination for travelers who will travel to Japan, Korea, Thailand; but for those who will travel to Indonesia, vaccination for this JE disease is not needed, since in Indonesia there is no JE virus or disease. 
In addition to preventing health problems during the trip, travelers are encouraged to do counseling or get pretravel advice from public health services that have the latest or up-to-date knowledge about diseases or viruses that are affecting certain countries, information about the environmental conditions and people lifestyles in destination countries, such as the sanitation in developing countries which are less concerned, a lot of garbage scattered on the roadside, unhealthy food or snacks that are offered to tourists, the cleanliness of toilets, etc.

Knowledge of environmental conditions and lifestyle of the community in destination countries is very important information for prospective traveler since the spread of viruses and diseases often caused by contamination and direct or indirect diseases transmission, the contaminated air, water, and food consumption can transmit bacteria and virus to people, it is in line with the statement of Division of Public Health, that the factors of transmitting diseases are through direct or indirect contact with new people or the community in the destination country, the examples of direct contact are touching, kissing, sexual contact, contact with oral secretions, or contact with body lesions, meanwhile the indirect contact infections diseases spread when an infected person sneezes or coughs, sending infectious droplets into the air, thus it is needed for the travelers to anticipate these causative factors by having any pieces of advice in pre-travel consultation and get vaccination. In addition, public health services working in the field of travel medicine should be expertise in considering the right medicines to prevent or cope with the health problems of travelers.

Travelers should anticipate the infectious diseases spread during traveling to also anticipate post-travel serious illness and reduce the risk of death, thus it is needed for the travelers to do a pre-travel consultation or counselling to get some information regarding to health before doing a travel and get certain vaccination depending on the anticipation of diseases in the destination country, and these kinds of services belong to the travel medicine practices. Thus, the objective of this study is to review and investigate the effect of travel medicine practices in reducing the risk of health during traveling and its contribution to anticipate the infectious diseases spread. In this study, the researcher did not include the contribution of travel medicine practices to the non-infectious diseases, since the infectious diseases have higher impact on travelers' health risk during the trip.

\section{SUBJECTS AND METHOD \\ 1. Study Design}

This was a systematic review conducted according to the guidelines and the statement Preferred Reporting Items for Systematic Reviews and Meta-Analysis (PRISMA). Three databases included Science Direct, Elsevier, and PubMed was used to identify all both empirical and review studies. That articles published from 2004 to 2018. Keywords included (1) Travel medicine practices, (2) Travel clinic services, (3) Travellers' health risks, (4) Infectious diseases anticipation (5) Travel related illness. 
2. Inclusive and Exclusive Criteria

The following key data were extracted (1) Types of infectious diseases that usually attack travelers during traveling, (2) types of anticipation regarding to travel medicine services, (3) the level of success of travel medicine practices for travelers' health during the trip, (4) the key outcomes of travel medicine practices to reduce the health risk during traveling.

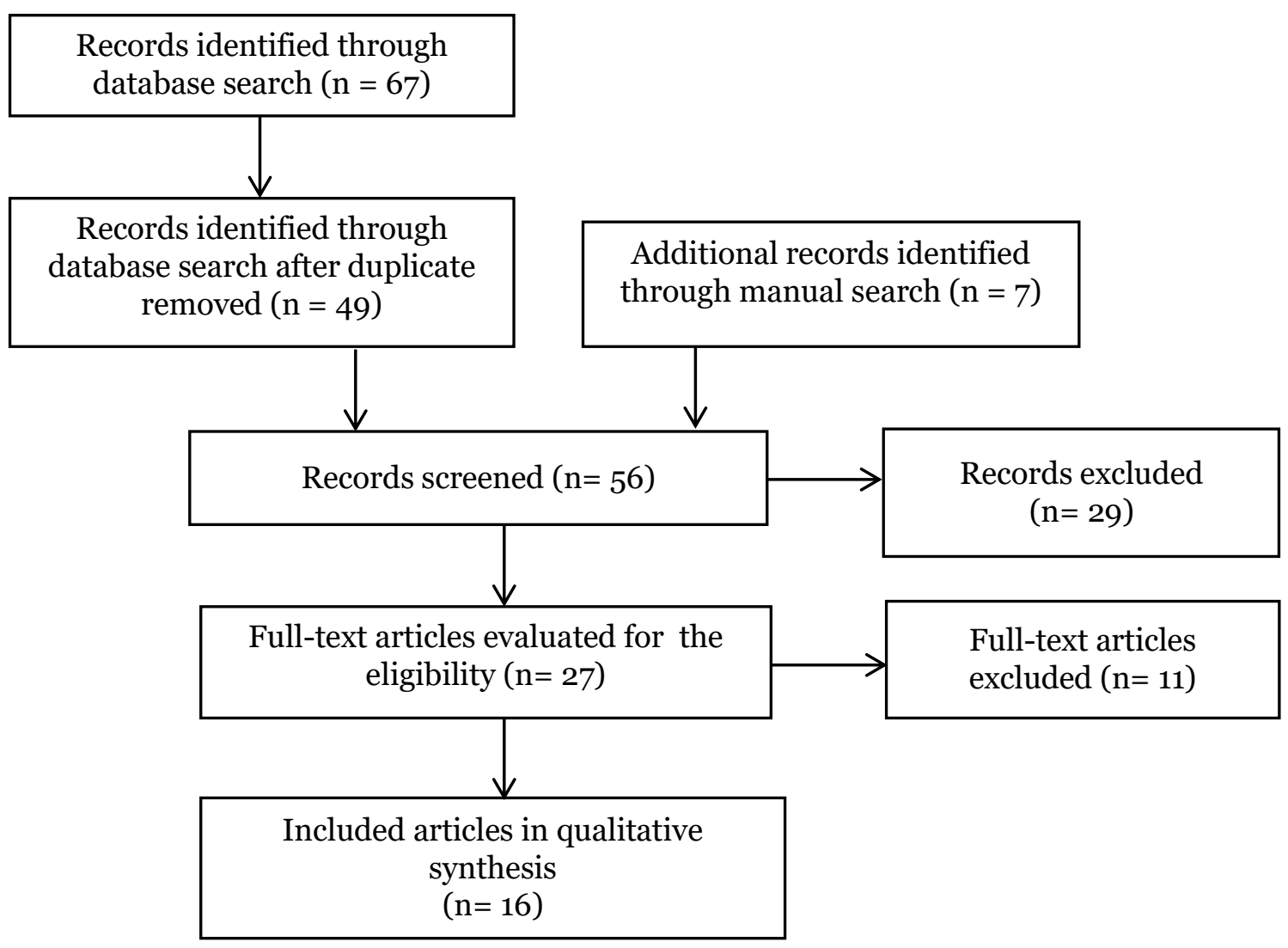

Figure 1. Flow diagram of Search Strategy

\begin{tabular}{lll}
\hline Table 1. Seven articles that are used in this study \\
\hline \multicolumn{1}{c}{ Author } & $\begin{array}{l}\text { Travel } \\
\text { Medicine } \\
\text { Practices }\end{array}$ & \multicolumn{1}{c}{ Findings } \\
\hline $\begin{array}{l}\text { Cornelisse } \\
\text { et al., 2018 }\end{array}$ & $\begin{array}{l}\text { Concealing, } \\
\text { vaccination and } \\
\text { did contracep- } \\
\text { tives }\end{array}$ & $\begin{array}{l}\text { The risk of Sexually Transmitted Infection (STIs) in } \\
\text { some destination countries that have high rates of } \\
\text { antimicrobial resistance (e.g. in Asian countries) can } \\
\text { be managed by preparing for sexual safety prior to } \\
\text { travel that can be provided by travel clinicians. }\end{array}$ \\
Aziz et al., & $\begin{array}{l}\text { Pre-travel } \\
\text { consultation and } \\
\text { immunizations } \\
\text { for vaccine- } \\
\text { preventable }\end{array}$ & $\begin{array}{l}\text { 60\%, 46.3\%, and 46.3\% of Umrah pilgrims believed in } \\
\text { importance of pre-travel vaccination, seeking health } \\
\text { information, and health examination. The most } \\
\text { frequently practiced pre-travel health-related behavior } \\
\text { was getting vaccinated (56.3\%), as compared to much }\end{array}$
\end{tabular}

The 5th International Conference on Public Health Best Western Premier Hotel, Solo, Indonesia, February 13-14, 2019 | 103 https://doi.org/10.26911/theicph.2019.01.26 


\begin{tabular}{ccc}
\hline Author & $\begin{array}{c}\text { Travel } \\
\text { Medicine } \\
\text { Practices }\end{array}$ & Findings \\
\hline diseases & $\begin{array}{l}\text { lower frequencies of seeking health information (24\%) } \\
\text { or having a clinical health examination (26.7\%). }\end{array}$
\end{tabular}
Aba et al., $\begin{aligned} & \text { Counseling and } \\ & \text { vaccination }\end{aligned}$
val8

Tan et al., Pre-travel 2018 consultation

Hoang et al., Vaccination 2018

Yezli et al., Vaccination 2018

Bühler et al., Pre-travel 2017
Travelers who provided vaccination certificate were significantly younger than travelers who did not (mean age: $34.8 \pm 17.8$ vs. $46 \pm 18.4$ years, $P<0.005$ ). Vaccine coverage against Tetanus, Diphtheria, and Poliomyelitis (Td/IPV vaccine) was $91.8 \%, 78.6 \%$ against Measles, Mumps, and Rubella (MMR), and 59.4\% against Viral Hepatitis B (HBV). BCG vaccine coverage was $71.9 \%$. Older travelers were less likely to be correctly vaccinated, except against $\mathrm{HBV}$ as vaccinated travelers were significantly older than unvaccinated travelers. Travel medicine consultations could be the opportunity to vaccinate against MMR, HBV, and Td/IPV.

The pre-travel consultation group had shorter hospital stays (mean 1.8 days for pre-travel versus 3.3 days for non-pre-travel consultation group, $\mathrm{p}=0.006$ ) and reduced gastroenterology consultation rates (OR 0.4; 95\% CI 0.2 to 0.9). It means that the pre-travel consultation group have a shorter duration of hospitalization and reduced need for gastroenterology consultation for prolonged or severe symptoms, which are positive outcomes that reflect reduced morbidity of travelers' diarrhea.

$55 \%$ of pilgrims had an indication for pneumococcal vaccination. Respiratory symptoms, fever and antibiotic intake were significantly more frequent in pilgrims with indication for vaccination against pneumococcal infection. The prevalence of $S$. pneumoniae carriage (1.8\% pre-, $9.8 \%$ post-Hajj), $H$. influenzae carriage $(0.9 \%, 45.4 \%)$ and $K$. pneumoniae $(2.8 \%, 9.8 \%)$ significantly increased post-Hajj. Pilgrims vaccinated with conjugate pneumococcal vaccine were seven-time less likely to present S.pneumoniae carriage post-Hajj compared to those not vaccinated $(3.2 \%$ vs. $18.0 \%, \mathrm{OR}=0.15 ; 95 \% \mathrm{CI}=$ 0.03 to $0.74 ; \mathrm{p}=0.02)$.

There was no official policy for vaccination against pneumococcal disease for pilgrims attending Hajj and Umrah events. Pilgrims awareness to have pneumococcal vaccination for Hajj and Umrah was still low. There were more people who recognize the importance of travel medicine consultations enhance the measles vaccination coverage in the adult Swiss population. Measles vaccination that was given during pre-travel consultations provided at travel clinics, play a key role in measles elimination and can contribute to a higher coverage in their catchment areas while preventing the possibility of being a source of measles outbreaks abroad.

The 5th International Conference on Public Health Best Western Premier Hotel, Solo, Indonesia, February 13-14, 2019 | 104 https://doi.org/10.26911/theicph.2019.01.26 


\begin{tabular}{|c|c|c|}
\hline Author & $\begin{array}{c}\text { Travel } \\
\text { Medicine } \\
\text { Practices }\end{array}$ & Findings \\
\hline $\begin{array}{l}\text { Wirawan } \\
\text { (2016) }\end{array}$ & $\begin{array}{l}\text { Pre-travel advice } \\
\text { and vaccination }\end{array}$ & $\begin{array}{l}\text { Some of the roles of travel medicine practices include; } \\
\text { role in terms of providing information on whether or } \\
\text { not a vaccination certificate is required, which is } \\
\text { related to the legal aspects of visiting an area, the other } \\
\text { role is in providing vaccination recommendations } \\
\text { needed to prevent certain diseases, and also give pra- } \\
\text { travel health advice. }\end{array}$ \\
\hline $\begin{array}{l}\text { Deshpande, } \\
\text { et al., } 2014\end{array}$ & Vaccination & $\begin{array}{l}\text { Clinicians were more likely to consider Japanese Ence- } \\
\text { phalitis vaccine to not be indicated for the travelers of } \\
\text { VFR (Visiting Friends and Relative) and travelers who } \\
\text { visit India, because not all regions of India are the } \\
\text { endemic for Japanese Encephalitis. }\end{array}$ \\
\hline $\begin{array}{l}\text { Sugitha and } \\
\text { Wande, } \\
2010\end{array}$ & $\begin{array}{l}\text { Pre-travel } \\
\text { consultation, } \\
\text { regular } \\
\text { medication, } \\
\text { close monitoring } \\
\text { of the condition } \\
\text { of the mother } \\
\text { and fetus during } \\
\text { the trip. }\end{array}$ & $\begin{array}{l}\text { The increasing number of tourists traveling to the } \\
\text { other countries will increase the risk of transmission of } \\
\text { infectious diseases, one of them is malaria. One group } \\
\text { that is susceptible to malaria infection in pregnant } \\
\text { women. The travelers should have pre-travel } \\
\text { counseling, especially for pregnant women who will } \\
\text { travel to tropical countries in Asia. }\end{array}$ \\
\hline $\begin{array}{l}\text { Reviono, } \\
2006\end{array}$ & $\begin{array}{l}\text { Health } \\
\text { consultation and } \\
\text { immunization }\end{array}$ & $\begin{array}{l}\text { In terms of its relevance to avian influenza, tourism } \\
\text { medicine plays a role in pre-tourism and post-tourism } \\
\text { services. In addition, pre-travel consultation services, } \\
\text { it is also important to provide health advice and } \\
\text { counseling services, especially the advice relating to } \\
\text { health problem and possible diseases infection when } \\
\text { traveling. }\end{array}$ \\
\hline $\begin{array}{l}\text { Ross et al., } \\
2006\end{array}$ & $\begin{array}{l}\text { Pre-travel advice } \\
\text { on rabies and } \\
\text { appropriate } \\
\text { post-travel } \\
\text { treatment }\end{array}$ & $\begin{array}{l}\text { Almost all physicians and pharmacists in the study } \\
\text { indicated that they would mention the risk of rabies } \\
\text { and appropriate preventive measures to long-term } \\
\text { travelers and tourists planning to visit rural areas. } \\
\text { However, only } 35 \% \text { to } 60 \% \text { of the advisors would } \\
\text { provide this information to individuals on business } \\
\text { trips, package tours, or travelers in urban centers as } \\
\text { well. }\end{array}$ \\
\hline $\begin{array}{l}\text { Leggat, } \\
2005\end{array}$ & $\begin{array}{l}\text { Pre-travel health } \\
\text { advice, } \\
\text { chemoprophylax } \\
\text { is against } \\
\text { travel-related di- } \\
\text { seases, traveler's } \\
\text { medical kits, } \\
\text { Travel } \\
\text { insurance, and } \\
\text { post-travel } \\
\text { assessments }\end{array}$ & $\begin{array}{l}\text { Travel and aviation medicine have many linkages, } \\
\text { especially in terms of fitness to fly and dealing with } \\
\text { problems that may arise in travelers due to } \\
\text { physiological and psychological stresses of travel. } \\
\text { Travel medicine practices have great importance in } \\
\text { travelers' planning. Travel insurance remains an } \\
\text { important safety net for travelers, which provides } \\
\text { coverage for medical and dental treatment abroad as } \\
\text { well as an emergency assistance service. }\end{array}$ \\
\hline $\begin{array}{l}\text { Van Herck, } \\
\text { et al., } 2004\end{array}$ & $\begin{array}{l}\text { Concealing and } \\
\text { vaccination }\end{array}$ & $\begin{array}{l}\text { Recommended travel health advice help travelers that } \\
\text { are visiting a high-risk area stay healthy while abroad } \\
\text { and consequently to also reduce the potential importa- } \\
\text { tion of infectious diseases and the consequent public } \\
\text { health and other implications. }\end{array}$ \\
\hline
\end{tabular}

The $5^{\text {th }}$ International Conference on Public Health Best Western Premier Hotel, Solo, Indonesia, February 13-14, 2019 | 105 https://doi.org/10.26911/theicph.2019.01.26 


\begin{tabular}{lll}
\hline Author & $\begin{array}{c}\text { Travel } \\
\text { Medicine } \\
\text { Practices }\end{array}$ & \multicolumn{1}{c}{ Findings } \\
\hline $\begin{array}{l}\text { Hamer, et } \\
\text { al., 2004 }\end{array}$ & $\begin{array}{l}\text { Pra-travel } \\
\text { concealing and } \\
\text { vaccination }\end{array}$ & $\begin{array}{l}\text { Travel medicine practices have raised people } \\
\text { awareness on the traveling American public about the } \\
\text { potential health risks associated with travel, the } \\
\text { importance of safe and effective preventive measures, } \\
\text { such as vaccines and malaria prophylaxis, and the } \\
\text { importance of being well prepared in terms of health } \\
\text { before travel. }\end{array}$ \\
$\begin{array}{lll}\text { Bacaner et } \\
\text { al., 2004 }\end{array}$ & $\begin{array}{l}\text { Pre-travel health } \\
\text { advice and } \\
\text { vaccination }\end{array}$ & $\begin{array}{l}\text { and mortality; moreover, it is also lower acute care } \\
\text { costs to the health care system. Since the immigrants } \\
\text { who are regularly visiting friends and relatives (VFRs) } \\
\text { will continue to be at high risk for travel-related } \\
\text { illness, thus it is needed to have potentially serious } \\
\text { personal and public health professionals who have a } \\
\text { good knowledge and professionalism in travel } \\
\text { medicine. }\end{array}$ \\
\hline
\end{tabular}

\section{DISCUSSION \\ 1. Types of travel medicine ser- vices}

\section{a. Pre-travel consultation}

In the pre-travel consultation, the clinicians do not only investigate the accomodation, climate condition, hygiene and sanitation, yet they should also investigate the pre-existing illness of the travelers and control the travelers' unhealthy behavior. According to the statement stated in World Health Organization book in the discussion about International travel and health (WHO, 2012).

Pre-travel consultation should consider various aspects including; details of tourist trips, activities to be carried out during the tour, risky diseases that may be owned by tourists, immunization or vaccination history, availability of health facilities and medicines at the travel destination. It has been stated above that pre-travel consultation is very beneficial in preventing diseases due to travellers who have been given some information about diseases and the environmental conditions of the community in the destination country. One of the most useful pre-travel consultation examples is the prevention of diarrhea, especially in the remote area as a travel destination. The most infectious diseases suffered by travelers when traveling are malaria, diarrhea, respiratory tract infection, hepatitis $\mathrm{A}$, hepatitis B, measles and Japanese Encephalitis. However, diarrhea is one of the most infectious diseases that is often become a health problem for most travelers (Wirawan, 2016; Tan, et.al., 2010; Leggat, 2005).

\section{b. Vaccination.}

Travelers should also get preventative vaccinations for certain diseases existed in the tourist destination country. People in developing countries or remote areas commonly have a lack of hygiene awareness, moreover viruses and bacteria more easily develop and spread in a country with a tropical climate or more temperate climate (Bacaner et al., 2004; Hill et al., 2006; Brian et al., 2014; Tan et al., 2018; Cornelisse, 2018). 


\section{Factors impacting travelers' serious health risks during the trip}

Factors impacting travelers' serious health risks during the trip included (1) The climate of destination countries; (2) duration and season of travel, purpose of travel; water quality and food hygiene; (3) The environmental sanitation in the destination countries; (4) Travelers' behavior and also; (5) Pre-existing illness of the travelers.

There are just a few people that are being aware to visit travel clinics to have pre-travel consultation and vaccination, while others do not have access to the travel clinics, especially in some developing countries. In some cases, people have a reason for not getting vaccinations for disease prevention before traveling or they consider that it is less necessary, they will go to psychiatric or hospital if they experience health problems or are seriously ill after traveling.

One of the examples in some cases that occurred in the Hajj and Umrah events, in which there are billions of people who came from all over the world, gathering together and worshiping in Mecca often contracted viral respiratory tract infections which were considered as normal condition by pilgrims during Hajj and Umrah events. Three current studies (Hoang, et al., 2018; Yezli, et al., 2018; and Aziz, et al., 2018) mentioned that pilgrims underestimate the importance of pre-travel consultation and vaccination to prevent the infectious diseases before having a trip or during the pilgrimage rituals. Many of the prospective pilgrims who carry out pilgrimage in Hajj and Umrah events already known the risk of diseases that are often experienced by the former pilgrims who experienced the diseases (e.g. viral respiratory tract infections). There is just a small number of the pilgrims that are desired to get vaccine-preventable diseases in Hajj and Umrah events. In addition, some people do not like to be vaccinated since they believe that vaccination have several side effects (Aziz, et.al, 2018). Based on the empirical studies reviewed in this paper that were conducted in the periods of 3 months to over 10 years, almost all of them show that travel medicine practices have a significant impact on the anticipation of infectious diseases, especially in pretravel consultation services and vaccination. Although few of them also mention that the clinicians or the travel medicine practitioners should improve their knowledge regarding the latest information about travelungrelated diseases, anticipation and treatment to also improve their services. A traveler's health and safety depend on a practitioner's level of expertise in providing pretravel counseling and vaccinations (Anari, et al., 2015). Further, it is also suggested to promote travel medicine services (Wirawan, 2016) to increase public awareness and understanding of the importance of having pre-travel health consultations and preventing the potential illnesses during a trip by taking preventive vaccinations.

\begin{tabular}{r}
\hline REFERENCE \\
\hline Aba YT, Gagneux-Brunon A, Andrillat \\
C, Fouilloux P, Daoud F, Defon- \\
taine C, et al. (2018). Travel me-
\end{tabular}


dicine consultation: An opportunity to improve coverage for routine vaccinations. Médecine et maladies infectieuses/Med Mal Infect; 4072.

Anari PY, Vaghefi M, Sepehri M, Therani DS, Habibi M (2015). Travel Medicine: A Systematic Review. International Journal of Travel Medicine and Global Health. 3(3):107-109.

Aziz MM, El-Megeed HSA, and Ellatif MAMA (2018). Pre-travel health seeking practices of Umrah pilgrims departing from Assiut International Airport, Egypt. Travel Medicine and Infectious Disease. 23: 72-76.

Bacaner N, Stauffer B, Boulware DR, Walker PF, Keystone JS (2004). Travel Medicine Considerations for North American Immigrants Visiting Friends and Relatives. Travel Medicine, JAMA. 291:23.

Brian AW, Boraston S, Botten D, Cherniwchan D, Fazal H, Kelton $\mathrm{T}$, et al. (2014). Travel medicine: What's involved? When to refer? Canadian Family Physician. 60:1091-1103.

Bühler S, Lang P, Bally B, Hatz C, Jaeger VK (2017). Stop measles in Switzerland The importance of travel medicine. Vaccine Journal. $\mathrm{xxx}$ in Elsevier Ltd.

Cermin Dunia Kedokteran Kesehatan Wisata (2006). ISSN: 0125-913X. Jakarta: Grup PT. Kalbe Farma Tbk.

Cornelisse VJ, Wright EJ, Fairley CK, McGuinness SL (2018). Sexual safety and HIV prevention in travel medicine: Practical considerations and new approaches.
Travel Medicine and Infectious Disease. Available online in the journal of Travel Medicine and Infectious Disease.

Deshpande BR, Rao SR, Jentes ES, Hills SL, Fischer M, Gershman MD, et al (2014). Use of Japanese Encephalitis Vaccine in US Travel Medicine Practices in Global TravEpiNet. The American Society of Tropical Medicine and Hygiene. 91(4): 694-698.

Hamer DH, Connor BA (2004). Travel Health Knowledge, Attitudes and Practices among United States Travelers. Journal of Travel Medicine. 11:23-26.

Hill DR, Ericsson CD, Pearson RD, Keystone JS, Freedman DO, Kozarsky PE, et al (2006). The practice of travel medicine: guidelines by the Infectious Diseases Society of America. Clin Infect Dis. 43:1499-1539.

Hoang VT, Meftah M, Anh Ly TD, Drali T, Yezli S, Alotaibi B, et al. (2018). Bacterial respiratory carriage in French Hajj pilgrims and the effect of pneumococcal vaccine and other individual preventive measures: A prospective cohort survey. Travel Medicine and Infectious Disease.

Leggat PA (2005). Travel medicine: an Australian perspective. Travel Medicine and Infectious Disease. 3: 67-75.

Reviono AR (2006). Peranan Ilmu Kedokteran Wisata dalam Pencegahan Penyebaran Avian Influenza stated in Cermin Dunia Kedokteran No. 152: 9-12.

Ross RS, Wolters B, Viazov SO, and 
Roggendorf M (2006). Awareness of Rabies Risks and Knowledge about Preventive Measures among Experienced German Travel Health Advisors: International Society of Travel Medicine, 1195-1982. Journal of Travel Medicine. 13(5): 261-267.

Sugitha KSL, Wande IN (2010). Peranan kedokteran wisata dalam upaya pencegahan dan penatalaksanaan malaria pada kehamilan.

Tan EM, St. Sauver JL, Sia IG (2018). Impact of pre-travel consultation on clinical management and outcomes of travelers' diarrhea: a retrospective cohort study. Tropical Diseases, Travel Medicine and Vaccines. 4: 16-24.

Van Herck K, Van Damme P, Castelli F, Zuckerman J, Nothdurft
H, Dahlgren AL, et al (2004). Knowledge, attitudes and practices in travel-related infectious diseases: the European airport survey. Journal of Travel Medicine. 11(1):3-8.

Wirawan IMA (2016). Kesehatan pariwisata: Aspek kesehatan masyarakat di daerah tujuan wisata. Arc. Com. Health. 3(1): ix - xiv.

World Health Organization: International Travel and Health. (2012). Switzerland: WHO Press. Available at: www.who.int/ith.

Yezli S, van der Linden M, Booy R, and AlOtaibi B (2018). Pneumococcal disease during Hajj and Umrah: Research agenda for evidence-based vaccination policy for these events. Travel Medicine and Infectious Disease. 1477-8939. 